\title{
A Case of Rheumatoid Nodules Involving the Larynx
}

\author{
Hee Won Seo ${ }^{1}$, Hae Won Choi ${ }^{1}$, Seong Sik Bang ${ }^{2}$, and Kyung Tae ${ }^{1}$ \\ ${ }^{1}$ Departments of Otolaryngology-Head and Neck Surgery, ${ }^{2}$ Pathology, College of Medicine, Hanyang University, Seoul, Korea
}

\author{
후두에 발생한 류마치스 결절 1예 \\ 서희원 ${ }^{1} \cdot$ 최해원 $^{1} \cdot$ 방성식 $^{2} \cdot$ 태 경 $^{1}$ \\ 한양대학교 의과대학 이비인후-두경부외과학교실, ${ }^{1}$ 조직병리학교실 ${ }^{2}$
}

\author{
Received April 5, 2019 \\ Revised May 31, 2019 \\ Accepted July 1, 2019 \\ Address for correspondence \\ Kyung Tae, MD, PhD \\ Department of Otolaryngology- \\ Head and Neck Surgery, \\ College of Medicine, \\ Hanyang University, \\ 222 Wangsimni-ro, Seongdong-gu, \\ Seoul 04763 , Korea \\ Tel $+82-2-2290-8585$ \\ Fax $+82-2-2293-3335$ \\ E-mail kytae@hanyang.ac.kr
}

About $40 \%$ of patients with rheumatoid arthritis show extra-articular manifestations. The presence of rheumatoid nodules is the most common extra-articular manifestation, which is commonly seen at pressure points. Rheumatoid nodules can also occur in the lung, heart, and larynx. Laryngeal rheumatoid nodules may lead to phonatory and respiratory symptoms and can be mistaken for other medical conditions such as inflammation and neoplasm. Recently, we encountered a case of rheumatoid nodules involving the larynx in a 56-year-old woman with a 3-year history of rheumatoid arthritis and Sjogren's syndrome. Herein, we report the case with a review of the literature.

Korean J Otorhinolaryngol-Head Neck Surg 2019;62(11):663-6

Key Words Larynx $\cdot$ Rheumatoid arthritis $\cdot$ Rheumatoid nodules.

\section{Introduction}

Rheumatoid arthritis is a chronic, systemic, inflammatory disease of unknown etiology that primarily involves the synovial joints. It usually leads to the destruction of joints by cartilage and bone erosion. The disease course is characterized by periods of remission and exacerbation. The disease usually progresses from the distal to proximal joints and results in significant locomotor disability between 10 and 20 years. 1 )

Although rheumatoid arthritis mostly occurs in the synovium of diarthrodial joints, about $40 \%$ of patients with rheumatoid arthritis show extra-articular manifestations involving the musculoskeletal system and non-articular organs. ${ }^{2)}$ Rheumatoid nodules are the most common extra-articular manifestation, which commonly occur on pressure points, such as

This is an Open Access article distributed under the terms of the Creative Commons Attribution Non-Commercial License (https://creativecommons.org/licenses/by-nc/4.0) which permits unrestricted non-commercial use, distribution, and reproduction in any medium, provided the original work is properly cited. the areas of olecranon, occiput, and ischium. ${ }^{3)}$ However, they can occur in other sites such as the lung, heart and larynx. ${ }^{4)}$

The laryngeal involvement of rheumatoid arthritis can be mistaken for other medical conditions such as inflammation and neoplasm. ${ }^{5)}$ Rheumatoid nodules involving the vocal cords may lead to phonatory and respiratory symptoms. ${ }^{6}$ )

Recently, we encountered a case of rheumatoid nodules involving the larynx. In this paper, we report the case with a review of the literature.

\section{Case}

A 56-year-old woman visited the otolaryngology department complaining of hoarseness and throat discomfort for 2 years. She had no symptoms of dysphagia or dyspnea.

She had suffered from rheumatoid arthritis and Sjogren's syndrome for 3 years and received disease-modifying antirheumatic drugs including methotrexate (MTX) and hydroxychloroquine. 
Flexible laryngoscopic examination revealed a mass-like lesion in the left supraglottic area, and the left vocal cord mobility decreased slightly (Fig. 1). Contrast-enhanced CT showed a $3 \times 3-\mathrm{cm}$ mass in the supraglottic region (Fig. 2). The mass involved the false vocal cord, pre-epiglottic space, both aryepiglottic folds, and paraglottic space.

Laryngeal microscopic surgery (LMS) for biopsy was performed under general anesthesia to rule out laryngeal cancer. The mucosa overlying the supraglottic mass was relatively intact, and a punch biopsy was performed including the mucosa and parenchymal tissue. The tissue sample was

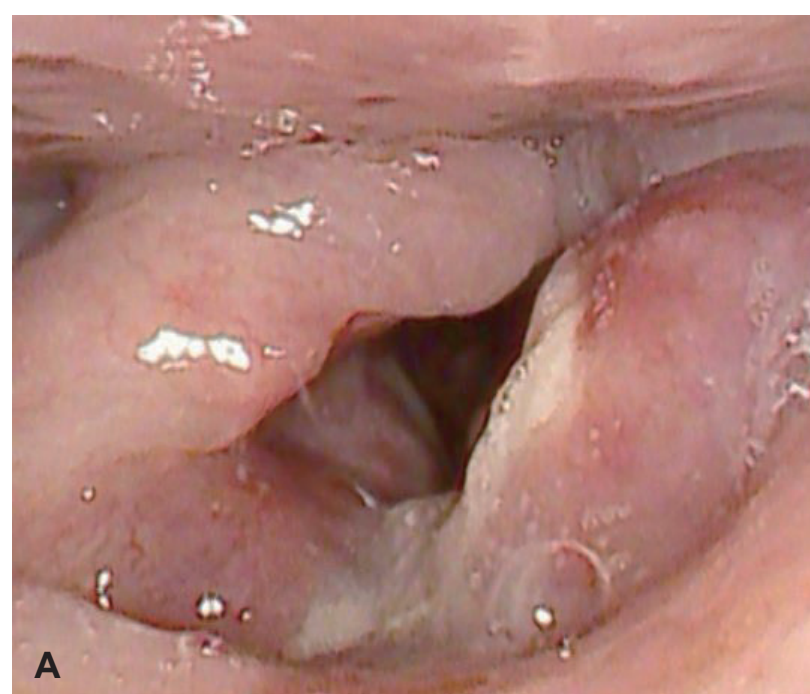

sent to the pathology department for a frozen biopsy, which showed a benign lesion without evidence of malignancy.

The postoperative course was uneventful, and there were no perioperative complications. Two weeks after the surgery, the biopsy result was confirmed as a rheumatoid nodule. The histopathology showed eosinophilic amorphous material scattered in the granulation tissue. Lymphocytic infiltration and fibrosis were also observed, and histiocytes and multinucleated giant cells surrounded the amorphous material (Fig. 3).

No further surgical interventions were performed for the laryngeal lesions, and the patient is being followed up at the

Fig. 1. Flexible laryngoscopic findings. The mass-like lesion is found in the left supraglottic region (A). The left vocal cord movement is slightly decreased (B).
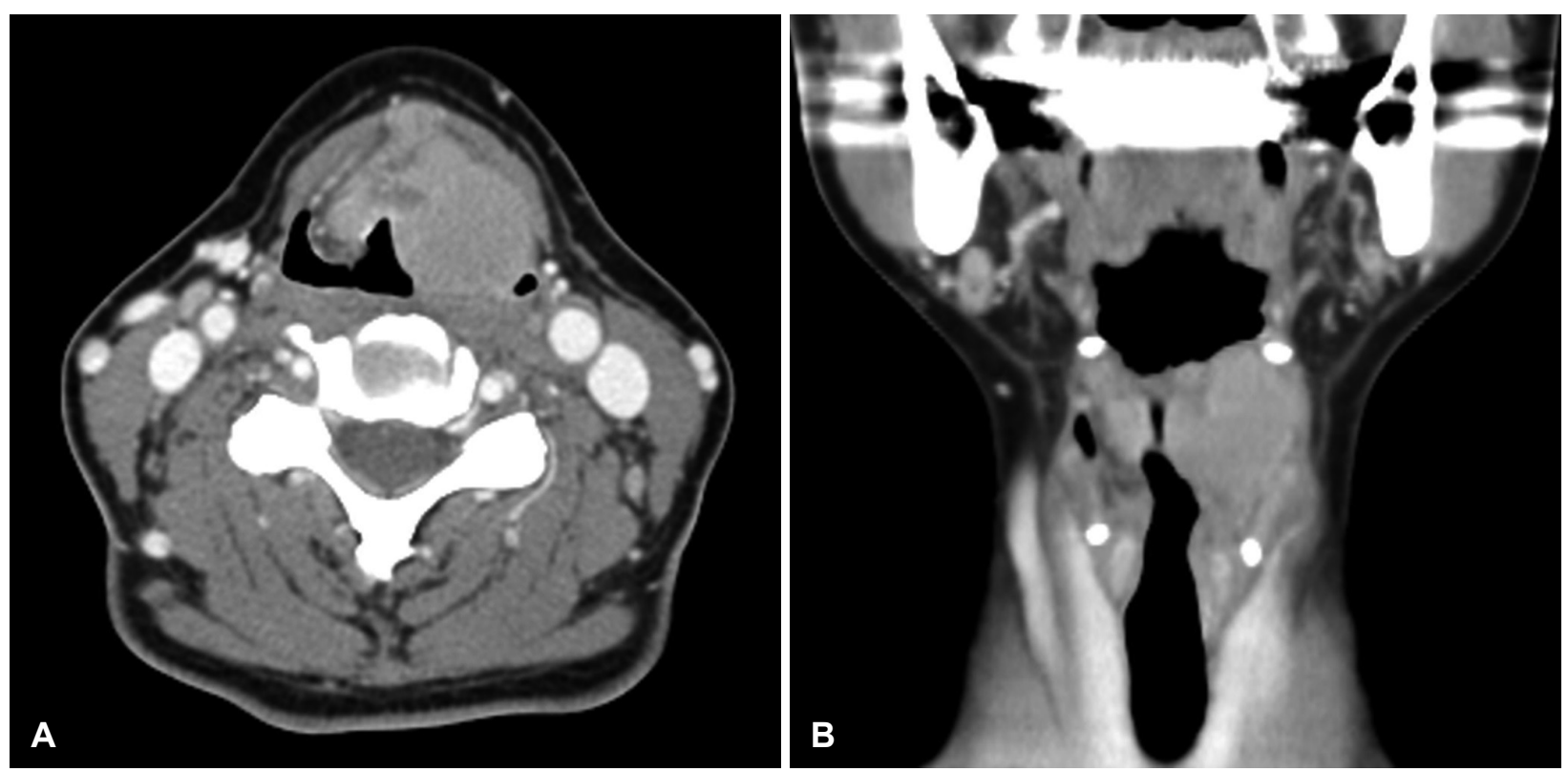

Fig. 2. Axial (A) and coronal (B) CT images show a $3 \times 3-\mathrm{cm}$ mass in the left supraglottic region involving the left false vocal cord, preepiglottic space, aryepiglottic folds, and paraglottic space. 


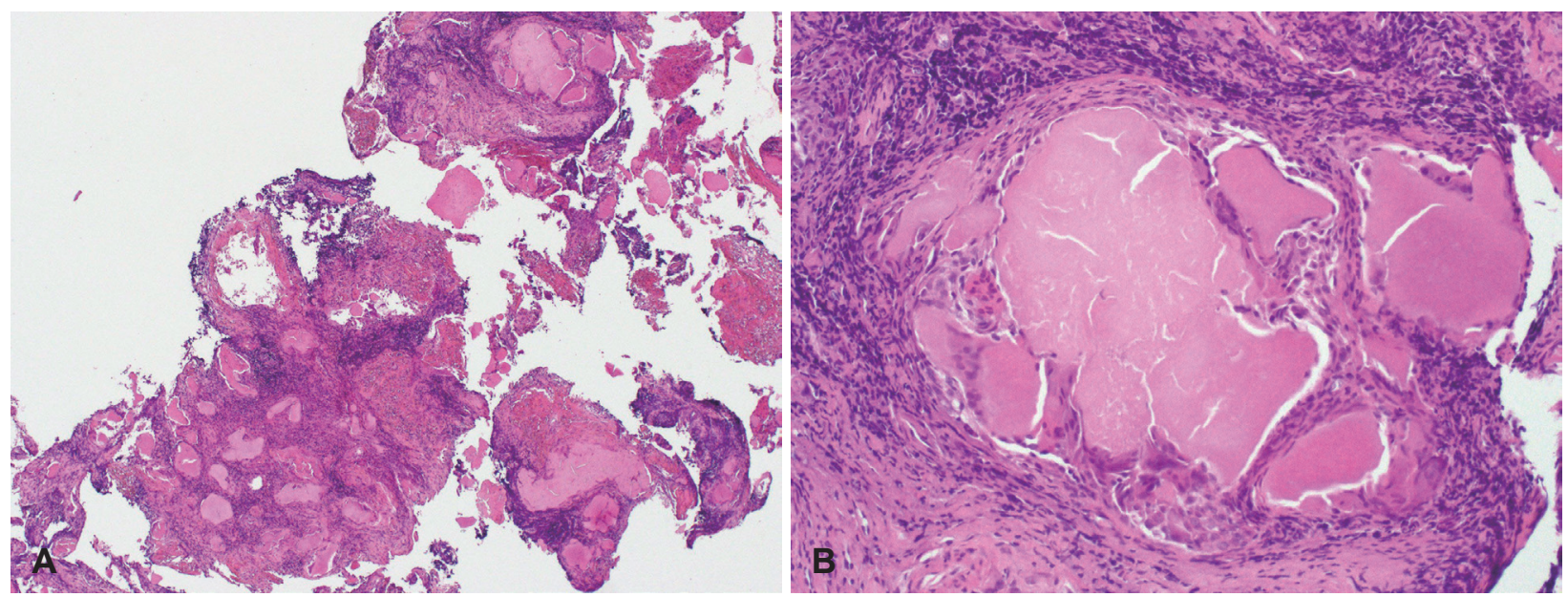

Fig. 3. Histopathological findings of rheumatoid nodules involving the supraglottis. Eosinophilic amorphous material is scattered in the granulation tissue. Lymphocytic infiltration and fibrosis are also observed (H\&E stain; $\times 40)(A)$. Histiocytes and multinucleated giant cells surround the amorphous material (H\&E stain; ×200) (B). H\&E: hematoxylin and eosin.

outpatient clinic while taking medications for rheumatoid arthritis including MTX, hydroxychloroquine, and low dose steroid therapy. In the 6-month follow-up visit, the supraglottic mass was stable without any increase in size.

\section{Discussion}

The extra-articular manifestations of rheumatoid arthritis, such as rheumatoid nodules and rheumatoid vasculitis, may cause a variety of ocular, pulmonary, gastrointestinal, cardiovascular, renal, neurological, and hematological symptoms rather than locomotor disabilities. ${ }^{7}$

The prevalence of laryngeal involvement in rheumatoid arthritis ranges from $0.3 \%$ to $12 \% .{ }^{2,8-11)}$ The most common laryngeal manifestation of rheumatoid arthritis is the involvement of the cricoarytenoid joint, occurring in about $66 \%$ of laryngeal involvement cases, which may cause cricoarytenoid joint fixation and airway obstruction." Other symptoms may include laryngeal mucosal edema, myositis of the intrinsic laryngeal muscles, inflammatory masses or rheumatoid nodules, and bamboo nodes. $\left.{ }^{6}\right)$ The clinical presentation of laryngeal rheumatoid nodules vary from being asymptomatic to causing life-threatening respiratory symptoms and include sore throat, cough, foreign body sensation, odynophagia, hoarseness, dysphonia, change in voice quality, and respiratory distress. ${ }^{5,6}$ The previous papers published in Korea have reported only two cases of vocal cord paralysis with cricoarytenoid joint fixation caused by rheumatoid arthritis. ${ }^{4,11)}$ To the best of our knowledge, this is the first case of rheumatoid nodules involving the larynx with voice change in Korea. In our case, the cause of decreased mobility of left vocal cord was due to the mass effect of rheumatoid nodule rather than cricoarytenoid joint fixation.

The diagnosis of laryngeal rheumatoid nodules needs a high degree of suspicion. CT, MRI, and laryngoscopic examination are useful for an early diagnosis. The final diagnosis can be made with histopathological examination. ${ }^{7)}$ In a case of laryngeal mass with rheumatoid arthritis, the possibility of rheumatoid nodules should be considered, and laryngeal cancer should be included in the differential diagnosis.

Laryngeal manifestations of rheumatoid nodules are rather benign, but sometimes they can be life-threatening. The treatment of rheumatoid nodules can be medical or surgical. In the early stages of the disease, medical treatment alone can be effective. The first-line medical treatment is the administration of steroids or nonsteroidal anti-inflammatory drugs to prevent the formation of nodules and fibrosis. ${ }^{12)}$ The steroids can be given systemically or locally for its anti-inflammatory effects.

MTX, which is widely used in the treatment of rheumatoid arthritis, may increase the size and number of rheumatoid nodules. ${ }^{13)}$ Therefore, if MTX is suspected to have caused the formation of rheumatoid nodules, discontinuing it can be considered. However, stopping MTX therapy is governed by several factors such as disease activity, drug availability, and cost concerns. ${ }^{14)}$

If the laryngeal rheumatoid nodules present with phonatory symptoms, voice therapy, steroid injection into the laryngeal mass or surgical intervention may be considered. However, in the presence of airway symptoms, surgical excision is neces- 
sary. In that case, LMS is performed under general anesthesia to remove the mass while preserving the overlying mucosa. In chronic cases where rheumatoid nodules invade the cricoarytenoid joint causing bilateral vocal cord fixation, an emergency tracheostomy is required. ${ }^{15)}$

In this study, the main symptom of patient is voice change, and there are no symptoms such as dyspnea and dysphagia. During 6 months of follow-up after diagnosis, the size of laryngeal rheumatoid nodule did not increase. Therefore, she has continued to take medication for rheumatoid arthritis rather than laryngeal surgery. However, if the size of rheumatoid nodule enlarges to cause dyspnea, stopping MTX or surgical excision will be necessary.

In conclusion, in rheumatoid arthritis patients with laryngeal mass, the possibility of rheumatoid nodules as well as laryngeal malignancy should be considered in the differential diagnosis of a laryngeal mass.

\section{ORCID}

Kyung Tae

https://orcid.org/0000-0002-0382-2072

\section{REFERENCES}

1) Jacoby RK, Jayson MI, Cosh JA. Onset, early stages, and prognosis of rheumatoid arthritis: A clinical study of 100 patients with 11year follow-up. Br Med J 1973;2(5858):96-100.

2) Turesson C, O'Fallon WM, Crowson CS, Gabriel SE, Matteson EL. Extra-articular disease manifestations in rheumatoid arthritis: Incidence trends and risk factors over 46 years. Ann Rheum Dis 2003;62(8):722-7.
3) Sayah A, English III JC. Rheumatoid arthritis: A review of the cutaneous manifestations. J Am Acad Dermatol 2005;53(2):191209.

4) Lee EJ, Joo YH, Kim JP, Woo SH. A case of bilateral vocal cord paralysis in a patient with rheumatoid arthritis. Korean J Otorhinolaryngol-Head Neck Surg 2011;54(3):235-38.

5) Haben CM, Chagnon FP, Zakhary K. Laryngeal manifestation of autoimmune disease: Rheumatoid arthritis mimicking a cartilaginous neoplasm. J Otolaryngol 2005;34(3):203-6.

6) Hamdan AL, Sarieddine D. Laryngeal manifestations of rheumatoid arthritis. Autoimmune Dis 2013;2013:103081.

7) Cojocaru M, Cojocaru IM, Silosi I, Vrabie CD, Tanasescu R. Extra-articular manifestations in rheumatoid arthritis. Maedica (Buchar) 2010;5(4):286-91.

8) Woo P, Mendelsohn J, Humphrey D. Rheumatoid nodules of the larynx. Otolaryngol Head Neck Surg 1995;113(1):147-50.

9) Beirith SC, Ikino CM, Pereira IA. Laryngeal involvement in rheumatoid arthritis. Braz J Otorhinolaryngol 2013;79(2):233-8.

10) Chen JJ, Branstetter BF 4th, Myers EN. Cricoarytenoid rheumatoid arthritis: An important consideration in aggressive lesions of the larynx. Am J Neuroradiol 2005;26(4):970-2.

11) Ahn CM, Moon KJ, Kim HC. Rheumatoid arthritis of the larynx: A case report. Korean J Otorhinolaryngol-Head Neck Surg 2002;45(5):522-5.

12) Dockery KM, Sismanis A, Abedi E. Rheumatoid arthritis of the larynx: The importance of early diagnosis and corticosteroid therapy. South Med J 1991;84(1):95-6.

13) Kerstens PJ, Boerbooms AM, Jeurissen ME, Fast JH, Assmann KJ, van de Putte LB. Accelerated nodulosis during low dose methotrexate therapy for rheumatoid arthritis. An analysis of ten cases. J Rheumatol 1992;19(6):867-71.

14) Matsushita I, Uzuki M, Matsuno H, Sugiyama E, Kimura T. Rheumatoid nodulosis during methotrexate therapy in a patient with rheumatoid arthritis. Mod Rheumatol 2006;16(6):401-3.

15) Tarnowska C, Amernik K, Matyja G, Brzosko I, Grzelec H, Burak M. [Fixation of the crico-arythenoid joints in rheumatoid arthritis-preliminary report]. Otolaryngol Pol 2004;58(4):843-9. 